\title{
Increasing Cigarette Excise Tax Prevents Smoking Initiation in Children and Finances National Health Insurance in Indonesia
}

\section{Kenaikan Cukai Rokok untuk Mencegah Inisiasi Merokok pada Anak-anak dan Pembiayaan Jaminan Kesehatan Nasional di Indonesia}

\author{
Ayu Tyas Purnamasari ${ }^{1}$, Pujiyanto ${ }^{1}$, Hasbullah Thabrany ${ }^{2}$, Renny Nurhasana ${ }^{3}$, \\ Aryana Satrya ${ }^{3}$, Teguh Dartanto ${ }^{4}$ \\ ${ }^{1}$ Faculty of Public Health Universitas Indonesia \\ ${ }^{2}$ Chair of the Indonesian Health Economists Association (InaHEA), Universitas Indonesia \\ ${ }^{3}$ Center for Social Security Studies, Universitas Indonesia \\ ${ }^{4}$ Faculty of Economics and Business, Universitas Indonesia \\ Corresponding Author: Ayu Tyas Purnamasari \\ e-mail:ayutyasp97@gmail.com
}

\begin{abstract}
Indonesia has ranked third among countries with the highest number of smokers in Asia because the price of cigarettes in those countries is still affordable. The strategy to make the price of cigarettes is not affordable is increasing cigarette excise tax. This instrument is considered the most effective way to control cigarette consumption. The purpose of this study was to find out how the public perceive the increase of the cigarette excise tax to cover the National Health Insurance (NHI) deficit and to identify the factors which affect such perception. This study used mobile phone survey and the sample were 1000 respondents. The list of potential respondent's mobile phone numbers was selected using the systematic random sampling method with an interval of 100,000 to 200,000. The result showed that $87.9 \%$ respondents agree to increase cigarette price so that the children do not start to smoke. The majority of respondents (86.2\%) also agree to increase the price of cigarettes to finance the JKN deficit. Perceptions of respondents who agreed to increase the price of cigarettes to prevent smoking initiation in children also tended to accede the increase in cigarette prices for financing the JKN deficit.

Keywords: sin tax, tobacco control, national health insurance, cigarette excise tax, NHI deficit
\end{abstract}

\begin{abstract}
Abstrak
Indonesia menempati peringkat ketika jumlah perokok tertinggi di Asia karena harga rokok masih terjangkau. Strategi agar harga rokok tidak terjangkau adalah menaikkan cukai rokok. Instrumen tersebut dinilai paling efektif untukmengendalikan konsumsi rokok. Tujuan penelitian adalah untuk mengetahui bagaimana persepsi masyarakat terhadap kenaikan cukai rokok untuk pembiayaan Jaminan Kesehatan Nasional (JKN) dan mengidentifikasi faktor yang memengaruhi persepsi tersebut. Metode penelitian menggunakan survei melalui telepon dengan sampel 1000 responden. Daftar nomor telepon seluler calon responden dipilih dengan cara systematic random sampling interval 100.000 sampai 200.000. Hasil penelitian menunjukkan bahwa 87,9\% setuju harga rokok dinaikkan agar anak-anak tidak mulai merokok. Mayoritas responden (86,2\%) juga setuju mengenai kenaikan harga rokok untuk pembiayaan defisit JKN. Persepsi responden yang setuju terhadap kenaikan harga rokok agar mencegah inisisasi merokok pada anak-anakjuga cenderung setuju terhadap kenaikan harga rokok untuk pembiayaan defisit JKN.

Kata kunci: pajak dosa, pengendalian tembakau, jaminan kesehatan nasional, cukai rokok, defisit JKN
\end{abstract}

\section{Introduction}

Smoking is one of the risk factors for noncommunicable diseases worldwide. Smoker prevalence in the world according to WHO is about 1.1 billion, while $80 \%$ have lived in the lowand middle-income countries. In terms of smoker prevalence, Indonesia ranks third among Asian countries (115 million) after China (317 million) and India (112 million) in 2008-2012 (Jha and Peto, 2014). The prevalence of Indonesian smokers aged $\geq 10$ years in 2018 was $28.8 \%$, but it only shows a $0.5 \%$ decrease from the prevalence in
2013 (Kementerian Kesehatan Republik Indonesia, 2018a). Although smoking prevalence declines in aggregate, the prevalence of smoking among youth increases. The number of smokers aged 10-18 years old escalates every year from about $7.2 \%$ in 2013 , $8.8 \%$ in 2016, and $9.1 \%$ in 2018 in spite of the 2018 target of $5.4 \%$ (Kementerian Kesehatan Republik Indonesia, 2018b).

Cigarette contains more than 7000 chemicals, around 69 of which can cause cancer (U.S. Department of Health and Human Services, 2010). 
Cigarette exposure causes adverse health effects in both active and passive smokers. Smoking is a major risk factor for cancer, chronic respiratory disease, cardiovascular disease, reproductive disorders, and diabetes (U.S. Department of Health and Human Services, 2014). Smoking-related mortality in Indonesia is 225,720 or $14.7 \%$ of all active and passive smokers in 2018. Cardiovascular disease and stroke are the most common causes of smokingrelated mortalities (World Health Organization, 2018).

Tobacco control is important to decrease health and economic burden caused by smoking. Indonesia is the only Southeast Asia country which does not ratify the United Nations Framework Convention on Tobacco Control (FCTC) and has become the fifth largest cigarette market country in the world (Webster, 2013). These facts demonstrate that the country has shown no commitment to implementing tobacco control, including cigarette excise tax increase. Cigarette tax is an effective way to regulate cigarette consumption.

Article 5 of the Excise Law No. 39 of 2007 mandates that the excise of tobacco-processed products shall be a maximum of $57 \%$ of the retail price, but the average increase in excise as specified in the Minister of Finance Regulation No. 147 of 2016 amounts to $43 \%$ of the retail price (Center for Health Economics and Policy Studies Universitas Indonesia, 2017). Increasing cigarette excise tax has been proven to reduce the prevalence of smoking among youth (Thomas et al., 2008; International Agency for Research on Cancer, 2011; Hill et al., 2014; Tabuchi et al., 2016).

Along with increasing cigarette consumption trend among youth, the prevalence of non-communicable diseases increases, as well (AstraZeneca, 2011; World Health Assembly, 2011). Since 2014 Indonesia has implemented the National Health Insurance or Jaminan Kesehatan Nasional (JKN); both terms are used interchangeably in this study. Chronic diseases caused by smoking absorbed $22 \%$ of total claims in 2016 (Moeloek, 2016).

JKN has undergone deficit since its first year of implementation, which reached IDR 9.8 billion in 2017 (Databoks, 2018). The amount of contribution set is far below the ideal amount, while the increasing number of catastrophic illnesses caused by smoking accounts for the deficit of JKN.
One of the solutions which can be applied to overcome JKN deficit and to control cigarette consumption is increasing cigarette excise tax and then allocating the revenue to cover the JKN deficit. Many countries have implemented a system which is also called "sin tax". This system has sparked fierce debates among various stakeholders, so the public support for the "sin tax" proposal is very important. Public perception can affect policymakers' decision and play a great role in the successful implementation of "sin tax" in Indonesia. The objectives of this study were to find out the people's perception of increasing cigarette excise tax to finance JKN and to observe its influencing factors.

\section{Method}

This study used secondary data from the Center for Social Security, Universitas Indonesia. Mobile phone survey was selected as the data collection technique of this research because there are 313 million registered mobile phone numbers, based on a report by the Ministry of Communication and Informatics (Bosnia, 2018). The survey was conducted in May 2018. The interview was conducted for 5 to 10 minutes per person and was held only weekdays from 08.00 a.m. to 08.00 p.m. The mobile phone numbers were selected using the random-digit dialing (RDD) technique to get first connecting mobile phone numbers. RDD is generally used in order to get representative samples for population research by means of mobile phone numbers (L'Engle et al., 2018).

In the RDD technique, a random number generator was used to assemble twelve-digit mobile phone numbers in Indonesia. The first three digits of a number were set to be the International mobile phone code of Indonesia $(+628)$. The following two digits indicated the mobile network operator. The next three digits were the home location register (HLR), and the remaining five digits were gotten obtained from the random number generator.

The first mobile phone number on the list was then called, and if the recipient was willing to be a participant, he or she was considered as the first respondent. To get subsequent mobile phone numbers, systematic random sampling was used with an interval of 100,000 to 200,000 . After 50 calls (inactive numbers included), the process was repeated from the start using RDD. Interviews 
were conducted until 1000 respondents were obtained. The main criterion of eligible respondents was that they had to be at least 18 years old. The exclusion criteria were that the numbers were not working, the numbers were not in service, the calls were not answered, the recipients were unwilling to be respondents, and the respondents could not complete the interview. Respondents who missed the calls or were unable to join the interview at that time could call back the interviewer to take the survey at a more convenient time. The next steps were data recording and analysis using statistical software. Data were processed using an univariate, bivariate, and multivariate analysis.

\section{Result}

This study analyzed the characteristics of respondents and found that the percentage of male respondents (62.3\%) was almost twice the percentage of female respondents (37.7\%). Half of the respondents were $<30$ years old $(53.2 \%)$ and had attended school for 6 to 12 years $(50.4 \%)$, which is equal to high school level. Meanwhile, $47.5 \%$ respondents worked as private employees, and 29.9\% respondents earned a monthly income of about IDR 5 to 10 million

The majority of respondents reported that they were JKN members (72.8\%), whereas $19.23 \%$ of them used the JKN services over the past one month. Respondents were interviewed about their perception of increasing cigarette excise tax to prevent smoking initiation in children, and $87.9 \%$ agreed. They also agreed on increasing cigarette excise tax for financing JKN (86.2\%). Almost all respondents agreed that smoking is harmful to health (95.8\%). Half of the respondents answered that they agreed on the haram fatwa on smoking (51.7\%).

We performed a separate analysis for respondents who were smokers. Most respondents who were smokers consumed 1 to 2 packs of cigarette in a day (57.92\%). The average of their daily total cigarette expenditure was IDR 24.300 or around USD 1.7. The most commonly consumed cigarette brands were Sampoerna (34.4\%) and Gudang Garam (19.6\%), while some smokers bought more than one brand. Smokers considered that cigarette prices were high nowadays (48.64\%), but others said that the prices were reasonable (44.67\%).

This study observed the behavior of smokers towards changes in cigarette prices and found that
$74.01 \%$ smokers would quit smoking if the cigarette price became IDR 70,000 or around USD 5 per pack. Nevertheless, the prices of cigarettes nowadays were far below that price. Almost all smokers admitted that smoking damaged their health (91.1\%). There were more smokers who had JKN than those who did not have JKN (34.6\%).

Table 1 shows the perception of increasing cigarette excise tax for financing JKN based on respondents' characteristics. The participants who agreed on the sin tax were almost evenly distributed in all age groups, but the age group with the largest proportion was 51-60 years (93.3\%).

More female participants $(89.7 \%)$ agreed on the sin tax than male participants did (84.1\%), although the gap was not large and significantly correlated $(\mathrm{p}=0.018) .87 .5 \%$ of respondents who studied for 6-12 years agreed on the sin tax. The number of respondents who agreed on the sin tax was almost the same in all groups based on income levels and professions. More non-smoker respondents concurred with the sin $\operatorname{tax}(89.4 \%)$ than smoker participants did (81.4\%), and a significance correlation $(\mathrm{p}=0.0005)$ was found in both groups.

Respondents who approved of increasing cigarette price in order that children may not start smoking also agreed on the sin tax (90.9\%), and these variables were significantly related to each other $(\mathrm{p}=0.0005)$. Respondents who had the perception that smoking is harmful $(87.3 \%)$ tended to agree more on the sin tax than those who did not (61.9\%), and these variables were significantly associated with each other $(\mathrm{p}=0.0005)$.

The existence of haram fatwa on smoking had a significant correlation with the perception of increasing cigarette excise tax for financing JKN $(\mathrm{p}=0.006)$, which means that the respondents who agreed on the haram fatwa also tended to agree on the $\sin \operatorname{tax}(89.2 \%)$.

Logistic regression was used to find out what the dominant variable was (Table 2). This logistic regression used the "enter" method with thirteen times modeling. Table 2 shows the final model of our logistic regression. The perception of increasing cigarette excise tax to prevent smoking initiation in children and the perception of the health risk of cigarette smoking had a significant correlation with each other $(\mathrm{p}<0.05)$, after adjusting them to the variables of age, education, profession, current smoking status, and haram fatwa. 
Table 1. Perception of Increasing Cigarette Excise Tax for Financing JKN

\begin{tabular}{|c|c|c|c|}
\hline \multirow[t]{2}{*}{ Variable } & \multicolumn{2}{|c|}{$\begin{array}{l}\text { Perception of increasing cigarette } \\
\text { excise tax for financing JKN }\end{array}$} & \multirow[t]{2}{*}{ p-value } \\
\hline & Disagree (\%) & Agree (\%) & \\
\hline \multicolumn{4}{|l|}{ Age } \\
\hline$<30$ years & 12.4 & 87.6 & \multirow{5}{*}{0.115} \\
\hline $30-40$ years & 14.5 & 85.5 & \\
\hline $41-50$ years & 20 & 80 & \\
\hline $51-60$ years & 6.7 & 93.3 & \\
\hline$>60$ years & 20 & 80 & \\
\hline \multicolumn{4}{|l|}{ Gender } \\
\hline Men & 15.9 & 84.1 & \multirow{2}{*}{$0.018^{*}$} \\
\hline Women & 10.3 & 89.7 & \\
\hline \multicolumn{4}{|l|}{ Education } \\
\hline$<6$ years & 14.8 & 85.2 & \multirow{3}{*}{0.595} \\
\hline $6-12$ years & 12.7 & 87.3 & \\
\hline$>12$ years & 14.9 & 85.1 & \\
\hline \multicolumn{4}{|l|}{ Profession } \\
\hline Unemployed & 11.9 & 88.1 & \multirow{5}{*}{0.835} \\
\hline Student & 14.3 & 85.7 & \\
\hline Entrepreneur & 15.3 & 84.7 & \\
\hline Private employee & 13.1 & 86.9 & \\
\hline Civil servant & 16.3 & 83.8 & \\
\hline \multicolumn{4}{|l|}{ Income range (IDR) } \\
\hline$<3$ million & 13.7 & 86.3 & \multirow{4}{*}{0.727} \\
\hline 3-4.9 million & 15.6 & 84.4 & \\
\hline 5-10 million & 12.4 & 87.6 & \\
\hline$>10$ million & 13.2 & 86.8 & \\
\hline \multicolumn{4}{|l|}{ Current smoking status } \\
\hline Smoker & 18.6 & 81.4 & \multirow{2}{*}{$0.0005^{\star *}$} \\
\hline Non-smoker & 10.6 & 89.4 & \\
\hline \multicolumn{4}{|c|}{$\begin{array}{l}\text { Perception of increasing cigarette excise tax } \\
\text { to prevent smoking initiation in children }\end{array}$} \\
\hline Disagree & 47.9 & 52.1 & \multirow{2}{*}{$0.0005^{* *}$} \\
\hline Agree & 9.1 & 90.9 & \\
\hline \multicolumn{4}{|l|}{ JKN membership } \\
\hline Non-member & 13.2 & 86.8 & \multirow{2}{*}{0.831} \\
\hline Member & 14 & 86 & \\
\hline \multicolumn{4}{|c|}{ JKN utilization over the past one month } \\
\hline No & 14.5 & 85.5 & \multirow{2}{*}{0.567} \\
\hline Yes & 12.1 & 87.9 & \\
\hline \multicolumn{4}{|c|}{$\begin{array}{l}\text { Perception of the health risk of cigarette } \\
\text { smoking }\end{array}$} \\
\hline Disagree & 38.1 & 61.9 & \multirow{2}{*}{$0.0005^{\star *}$} \\
\hline Agree & 12.7 & 87.3 & \\
\hline \multicolumn{4}{|c|}{ Perception of haram fatwa on smoking } \\
\hline Disagree & 17 & 83 & \multirow{2}{*}{$0.006^{* *}$} \\
\hline Agree & 10.8 & 89.2 & \\
\hline
\end{tabular}


Table 2. Model of Logistic Regression

\begin{tabular}{|c|c|c|c|c|c|c|}
\hline \multirow{2}{*}{ Variable } & \multirow{2}{*}{ B } & \multirow{2}{*}{ S.E. } & \multirow{2}{*}{ Sig. } & \multirow{2}{*}{$\operatorname{Exp}(B)$} & \multicolumn{2}{|c|}{ 95\% C.I. } \\
\hline & & & & & Lower & Upper \\
\hline Age (Ref: <30 years) & & & 0.133 & & & \\
\hline 30-40 years & -0.162 & 0.249 & 0.517 & 0.851 & 0.522 & 1.387 \\
\hline $41-50$ years & -.646 & 0.307 & $0.035^{\star}$ & 0.524 & 0.287 & 0.956 \\
\hline $51-60$ years & 0.885 & 0.698 & 0.205 & 2.423 & 0.617 & 9.517 \\
\hline$>60$ years & -0.077 & 0.785 & 0.922 & 0.926 & 0.199 & 4.317 \\
\hline \multicolumn{7}{|l|}{ Education } \\
\hline \multicolumn{7}{|l|}{ (Ref: $<6$ years) } \\
\hline $6-12$ years & 0.240 & 0.437 & 0.582 & 1.272 & 0.540 & 2.995 \\
\hline$>12$ years & -0.355 & 0.449 & 0.430 & 0.701 & 0.291 & 1.692 \\
\hline $\begin{array}{l}\text { Profession } \\
\text { (Ref: Unemployed) }\end{array}$ & & & 0.437 & & & \\
\hline Student & -0.487 & 0.446 & 0.274 & 0.614 & 0.256 & 1.471 \\
\hline Entrepreneur & 0.280 & 0.392 & 0.475 & 1.323 & 0.614 & 2.854 \\
\hline Private employee & 0.073 & 0.349 & 0.836 & 1.075 & 0.542 & 2.133 \\
\hline Civil servant & -0.069 & 0.474 & 0.885 & 0.934 & 0.369 & 2.365 \\
\hline \multicolumn{7}{|l|}{ Current Smoking Status } \\
\hline $\begin{array}{l}\text { Non-smoker } \\
\text { (Ref: Smoker) }\end{array}$ & 0.339 & 0.233 & 0.145 & 1.404 & 0.889 & 2.217 \\
\hline \multicolumn{7}{|c|}{$\begin{array}{l}\text { Perception of increasing } \\
\text { cigarette excise tax to prevent } \\
\text { smoking initiation in children }\end{array}$} \\
\hline $\begin{array}{l}\text { Agree } \\
\text { (Ref: Disagree) }\end{array}$ & 2.180 & 0.234 & $0.000^{\star *}$ & 8.847 & 5.588 & 14.005 \\
\hline \multicolumn{7}{|c|}{$\begin{array}{l}\text { Perception of the health risk } \\
\text { of cigarette smoking }\end{array}$} \\
\hline Agree (Ref: Disagree) & 0.970 & 0.406 & $0.017^{\star}$ & 2.638 & 1.190 & 5.849 \\
\hline \multicolumn{7}{|c|}{$\begin{array}{l}\text { Perception of haram fatwa on } \\
\text { smoking }\end{array}$} \\
\hline Agree (Ref: Disagree) & 0.179 & 0.223 & 0.421 & 1.196 & 0.773 & 1.851 \\
\hline
\end{tabular}

Based on the results (Tabel 2), the odds ratio (OR) of the perception of increasing cigarette excise tax to prevent smoking initiation in children variable was 8.847 (95\%; CI: 5.588-14.005). This means that the odds of people who agreed on increasing cigarette prices in order to prevent children from starting to smoke agreeing on increasing cigarette excise tax to cover JKN were eight times higher than the odds of people who did not agree on that idea.

The odds ratio (OR) of the perception of the health risk of cigarette smoking was 2.638 (95\%; CI: 1.190-5.849). This suggests that the odds of people who agreed that smoking damages health agreeing on increasing cigarette excise tax for financing JKN were three times higher than the odds of people who did not agree on that idea. The dominant variable which correlated with increasing cigarette excise tax to fund JKN shortage was the perception of increasing cigarette prices in order to prevent children from starting to smoke.

\section{Discussion}

Increasing taxes on tobacco by raising the price of tobacco products such as cigarette has been proven to be the most effective way to reduce cigarette consumption and to encourage smokers to quit smoking (WHO Tobacco Free Initiative, 2004). The government received more revenues from the increased ex- 
cise tax, which can be used for organizing tobacco control, health, and social programs (WHO, 2008). Singapore decided to introduce a $10 \%$ increase in all tobacco products in 2018 and impose a 42.7 cents excise tax on every gram, part, or stick of clove cigarettes and other cigarettes containing tobacco. Other manufactured tobacco products or manufactured cigarettes are subject to an excise tax of $\$ 388.00$ per $\mathrm{kg}$, while other tobacco products for smoking, either packed or unpacked for retail sale, are subject to an excise tax of $\$ 427.00$ per $\mathrm{kg}$ (Singapore Customs, 2018). These taxes are transferred to Government's consolidated funds. Tobacco Control Fund in Switzerland is financed by an earmarked tax of $0.26 \mathrm{CHF}$ per pack of cigarettes (WHO Regional Office for Europe, 2007).

Many countries have allocated the tobacco excise tax to assure the sustainability of their health insurance programs. The Philippines allotted $85 \%$ of the incremental revenues from the tobacco excise tax to finance its universal health coverage, the result of which was that 10.8 million poor families were covered by the National Health Insurance Program or NHIP (Global Tobacco Free Kids, 2017). Egypt adopted a different policy of disbursing the tobacco excise tax for student's health insurance, while Congo expended half of the excise tax on health insurance (Tan, 2016).

Indonesia has prepared a strategic policy of tax earmarked for the national health insurance as has been introduced in other countries. To achieve the tax's purposes, the Indonesian government needs public support before implementing the policy on increasing cigarette excise tax to reduce the debt incurred by the country's national health insurance. People's perception of an increase in cigarette tax for financing JKN, that is, whether they agree or disagree on the idea, is influenced by many factors.

Being one of those factors, gender has a correlation with the perception of increasing cigarette excise tax for financing JKN. In line with a previous study, female members of the society were significantly more likely to support an earmarked tax (Hamilton et al., 2005). One possible explanation for this is the fact that women are more concerned about smoking risks and agreeable to tobacco control program. Participants' current smoking status is also related to their perception of increasing cigarette excise tax for financing JKN. This is consistent with earlier findings which suggest that smokers are less likely to support the tax increase if funds are earmarked for health care (Vardavas et al., 2012). Smokers who oppose the price increase are more likely to be driven by self-interest (Gardner and West, 2010). It seems that any increase in cigarette excise tax is considered as a disadvantage to smokers since they will spend more money to buy cigarette.

This finding demonstrates that there is a relationship between perception of the health risk of cigarette smoking and perception of increasing cigarette excise tax for financing JKN. People who agree on the long-term and short-term smoking-related risks tend not to be smokers themselves (Song et al., 2009).

Perception of smoking-related risks plays a significant role in reducing or preventing smoking habit; hence, it can strengthen the support for tobacco control which includes increasing the cigarette tax (Park et al., 2015). The current results show that perception of haram fatwa on smoking is related to perception of increasing cigarette excise tax for financing JKN. Indonesia has the largest Muslim population in the world, while almost all affairs which are classified as haram (prohibited) in Islam are also considered as unlawful actions. The Grand Mufti of Egypt has stated that smoking is haram (prohibited) in Islam (Ghada N. et al., 2003). The reasons why smoking is classified as haram are because cigarette consumption can lead to harmful effects on health and because buying cigarette is considered as wasting money, an action which is in contravention of Islamic teachings (Ghouri, Atcha and Sheikh, 2006).

This study found that perception of increasing cigarette excise tax to prevent smoking initiation in children was related to perception of increasing the cigarette excise tax for financing JKN and became the dominant variable. People understand that cigarette is harmful and they hope that children will never start to smoke. It is in line with the results of several previous case studies carried out in California and Australia which offer strong evidence that comprehensive tobacco control was able to reduce the rate of smoking initiation in youth (Pierce, White and Emery, 2012). A significant increase in cigarette tax can prevent potential users such as children from consuming cigarette (Boonn, 2018). Tobacco control programs, especially cigarette excise tax increases, offer many benefits such as preventing smoking initiation in children and covering the deficit of National Health Insurance. Therefore, people 
who had good perception of increasing the cigarette excise tax to prevent smoking initiation in children also tend to have good perception of increasing the cigarette excise tax for financing JKN.

There are no significant differences in the perception of increasing the cigarette excise tax for financing JKN across different variables, i.e. age group, residential area, education level, profession, income level, JKN membership status, and JKN utilization, over the past one month. This is consistent with an earlier study which found that the rate of support for increasing tobacco tax earmarked for health care does not significantly differ across various age groups, income levels, and education levels (Vardavas et al., 2012). It is likely that participants from all groups actually share the same positive attitude towards increasing cigarette excise tax for covering JKN. This can be a good piece of information for the government, so they do not have to be overly concerned about people's perception if they choose to increase the cigarette excise tax earmarked for JKN. In addition to that, this may also serve as evidence that the Indonesian President's pledge to increase excise revenues is wholly supported by the public (Thabrany and Laborahima, 2016).

\section{Conclusion and Recommendation Conclusion}

An increase in the cigarette excise tax to cover the debt of JKN is one of the solutions to maintain JKN sustainability. The majority of respondents agreed on increasing the cigarette excise tax for financing JKN. The variables of gender, current smoking status, perception of increasing the cigarette excise tax to prevent smoking initiation in children, perception of the health risk of cigarette smoking, perception of haram fatwa on smoking have correlation with perception of increasing cigarette excise tax for financing JKN. This finding is in line with those of previous studies about increasing cigarette excise tax and earmarked tax in other countries. Meanwhile, perception of increasing cigarette excise tax to prevent smoking initiation in children is the dominant factor which affects people's perception of increasing cigarette excise tax for financing JKN. This study can serve as evidence for the government that seeks to implement cigarette tax increase for financing JKN because the results have proven that the idea is greatly supported by the public.

\section{References}

Boonn, A. 2018. Raising cigarette taxes reduces smoking, especially among kids (and the cigarette companies know it). Washington, District of Columbia. Accessed: 6 January 2019 <www.Tobaccofreekids. Org/Research/Factsheets/Pdf/0146.Pdf>

Bosnia, T. 2018. Blokir Berlaku, Ada 63 Juta Nomor HP yang Belum Teregistrasi. Accessed: 13 December 2018 <https://www.cnbcindonesia.com/ fintech/20180301112651-37-5879/blokir-berlaku-ada-63-juta-nomor-hp-yang-belum-teregistrasi>.

CTFK. 2016. The Toll of Tobacco in Indonesia. Accessed: 6 May 2019 <https://www.tobaccofreekids.org/problem/toll-global/asia/indonesia>.

Databoks. 2018. Defisit dan Penyertaan Pemerintah ke BPJS Kesehatan (2014-2017). Accessed: 15 December 2018 <https://databoks.katadata.co.id/ datapublish/2018/05/17/2017-defisit-bpjs-kesehatan-rp-975-triliun>

Gardner, B. and West, R. 2010. Public support in England for raising the price of cigarettes to fund tobacco control activities. BMJ Open. 19(4): 331-333.

Ghada N., R. et al. 2003. Impact of religious rulings (Fatwa) on smoking. Journal of the Egyptian Society of Parasitology. 33(3):1087-1101.

Ghouri, N., Atcha, M. and Sheikh, A. 2006. Public health Influence of Islam on smoking among Muslims. BMJ Open. 332: 291-294.

Global Tobacco Free Kids. 2017a. Tobacco Tax Success Story, Global Tobacco Free Kids. Accessed: 18 January 2019 <https://www.tobaccofreekids.org/assets/global/pdfs/en/success_Philippines_en.pdf $>$.

Global Tobacco Free Kids. 2017b. Tobacco Tax Success Story, Global Tobacco Free Kids. Accessed: 18 January 2019 < https://www.tobaccofreekids.org/assets/global/pdfs/en/success_Philippines_en.pdf $>$.

Hamilton et al. 2005. Who Supports Tobacco Excise Taxes? Factors Associated With Towns' and Individuals' Support in Massachusetts. Journal of Public Health Management \& Practice. 11(4): 333-340. van Hasselt, M. et al. 2015. The relation between tobacco taxes and youth and young adult smoking: What happened following the 2009 U.S. federal tax increase on cigarettes?. Addictive Behaviors. 45: 104-109.

Hidayat, B. et al. 2017. Ringkasan Studi : Menentukan Harga Rokok Ideal. Depok: Center for Health Economics and Policy Studies Universitas Indonesia. Hill, S. et al. 2014. Impact of tobacco control inter- 
ventions on socioeconomic inequalities in smoking: Review of the evidence. Tobacco Control. $23(\mathrm{e} 2)$ : e89-e97.

International Agency for Research on Cancer. 2011. IARC Handbooks of Cancer Prevention Tobacco Control Volume 14: Effectiveness of Tax and Price Policies for Tobacco Control, World Health Organization.

Jha, P. and Peto, R. 2014. Global Effects of Smoking, of Quitting, and of Taxing Tobacco. The New England Journal of Medicine. 370(1): 60-68.

Kementerian Kesehatan Republik Indonesia. 2018a. Hasil Utama RISKESDAS 2018. Badan Penelitian dan Pengembangan Kesehatan. Jakarta:Kementerian Kesehatan Republik Indonesia. p.123-124.

Kementerian Kesehatan Republik Indonesia. 2018b. Hasil Utama RISKESDAS 2018, Badan Penelitian dan Pengembangan Kesehatan. Jakarta:Kementerian Kesehatan Republik Indonesia. p.125.

Kostiva, D. et al. 2010. Prices and Cigarette Demand: Evidance from Youth Tobacco Use in Developing Countries. 15781. Cambridge.

L'Engle, K. et al. 2018. Survey research with a random digit dial national mobile phone sample in Ghana: Methods and sample quality. PLoS ONE. 13(1): $1-11$.

Moeloek, N. 2016. Pengantar Dialog: Dialog Konstruktif Pemangku Kepentingan untuk Peningkatan JKN”.' Jakarta, 30 May 2016.

Park, E. J. et al. 2015 'What cigarette price is required for smokers to attempt to quit smoking? Findings from the ITC Korea waves 2 and 3 survey', Tobacco Control. 24(2008): iii48-iii55.

Pierce, J. P., White, V. M. and Emery, S. L. 2012. What public health strategies are needed to reduce smoking initiation?. Tobacco Control. 21(2): $258-264$.

Singapore Customs (2018) List of Dutiable Goods, Government of Singapore. Accessed: 20 February 2019 <Available at: https://www.customs.gov. sg/businesses/valuation-duties-taxes--fees/duties-and-dutiable-goods/list-of-dutiable-goods $>$.

Song, A. V. et al. 2009. Perceptions of smoking-related risks and benefits as predictors of adolescent smoking initiation. American Journal of Public Health. 99(3): 487-492.

Tabuchi, T. et al. 2016. Tobacco Price Increase and Smoking Cessation in Japan, a Developed Country With Affordable Tobacco: A National Popula-
tion-Based Observational Study. Journal of Epidemiology. 26(1):14-21.

Tan, Y. L. 2016 Earmarked tobacco taxes : Lesson learnt from nine countries. Geneva: World Health Organization.

Thabrany, H. and Laborahima, Z. 2016. People's Support on Sin Tax to Finance UHC in Indonesia, 2016, Jurnal Ekonomi Kesehatan Indonesia. 1 (1):1-11. The AstraZeneca Young Health Programme. 2011. Non-Communicable Diseases and Adolescents: An opportunity for action. Cambridge. p. 1-20.

Thomas, S. et al. 2008. Population tobacco control interventions and their effects on social inequalities in smoking: Systematic review. Tobacco Control.17(4): 230-237.

U.S. Department of Health and Human Services. 2010. How Tobacco Smoke Causes Disease: The Biology and Behavioral Basis for Smoking-Attributable Disease: A Report of the Surgeon General., U.S. Department of Health and Human Services, Centers for Disease Control and Prevention, National Center for Chronic Disease Prevention and Health Promotion, Office on Smoking and Health.

U.S. Department of Health and Human Services. 2014. The Health Consequences of Smoking-50 Years of Progress A Report of the Surgeon General. A Report of the Surgeon General. p. 1081.

Vardavas, C. I. et al. 2012. Tobacco taxation: The importance of earmarking the revenue to health care and tobacco control. Tobacco Induced Diseases. 10(1): $1-6$

WHO. 2008. MPOWER: Six policies to reverse the tobacco epidemic. World Health Organization, pp. 23-41.

WHO Regional Office for Europe. 2007. The European Tobacco Control Report: 2007. Denmark: World Health Organization Europe.

WHO Tobacco Free Initiative. 2004. Building blocks for tobacco control: a handbook. Geneva.

World Bank. 2017. Total Population. Accessed: 6 May 2019 <https://data.worldbank.org/indicator/ sp.pop.totl>

World Health Assembly. 2011. Youth and health risks. World Health Organization. A64.28(May), pp. $1-4$.

World Health Organization. 2018. Factsheet 2018 Indonesia. p. 2. doi: 10.1056/ NEJM200208153470717. 